\title{
Atherectomy-assisted versus percutaneous angioplasty interventions for treatment of symptomatic infra-inguinal peripheral arterial disease
}

Obai Abdullah ${ }^{1}$, Jad Omran ${ }^{2}$, Ashraf S. Al-Dadah ${ }^{3}$ Kul Aggarwal ${ }^{1}$, Tariq Enezate ${ }^{1}$

\author{
${ }^{1}$ Cardiovascular Medicine Department, University of Missouri, Columbia School \\ of Medicine, USA \\ 2Division of Cardiovascular Medicine, University of California, San Diego, USA \\ ${ }^{3}$ Prairie Heart Institute, O'fallon, IL, United States
}

Submitted: 30 June 2019

Accepted: 6 August 2019

Arch Med Sci Atheroscler Dis 2019; 4: e231-e242

DOI: https://doi.org/10.5114/amsad.2019.89900

Copyright $\odot 2019$ Termedia \& Banach

\section{Abstract}

Introduction: The role of atherectomy (ATHERO) for the treatment of symptomatic infra-inguinal arterial lesions remains controversial. We evaluated the effectiveness and safety of atherectomy-assisted endovascular interventions in comparison with percutaneous angioplasty (PTA).

Material and methods: A systematic search utilizing MEDLINE, EMBASE and the Cochrane Central Register of Controlled Trials was conducted for studies comparing ATHERO with PTA from February 1995 to May 2018. Only studies comparing ATHERO to PTA for symptomatic infra-inguinal disease were included. Random-effects meta-analysis was used to pool the data and endpoints across studies. Study endpoints included vessel dissection, distal embolization, residual stenosis (>30\%), vessel patency at 6 months, target lesion revascularization (TLR) at 12 months and major amputation rates at 1,6 , and 12 months.

Results: A total of 2923 patients were included from 8 studies. PTA was associated with higher vessel dissection $(\mathrm{OR}=4.00,95 \% \mathrm{Cl}: 1.15-13.86)$ and lower 12 -month major amputation rates $(\mathrm{OR}=0.73,95 \% \mathrm{Cl}: 0.59-0.90)$. There was no significant difference between ATHERO and PTA groups in terms of distal embolization ( $\mathrm{OR}=0.45,95 \% \mathrm{Cl}: 0.04-4.63)$, residual stenosis $(\mathrm{OR}=1.28,95 \% \mathrm{Cl}: 0.58-2.80)$, vessel patency at 6 months $(\mathrm{OR}=1.27$, $95 \% \mathrm{Cl}: 0.50-3.22)$, TLR at 12 months $(\mathrm{OR}=1.07,95 \% \mathrm{Cl}: 0.46-2.51)$, or limb amputation at 1 month $(\mathrm{OR}=0.69,95 \% \mathrm{Cl}: 0.44-1.07)$ or 6 months $(\mathrm{OR}=$ $1.54,95 \% \mathrm{Cl}: 0.38-6.15)$.

Conclusions: In patients undergoing infra-inguinal endovascular interventions, PTA was associated with higher peri-procedural vessel dissection and lower 12-month major amputation rates. Both modalities were associated with similar distal embolization, residual stenosis, and 6-month vessel patency and amputation rates.

Key words: atherectomy, percutaneous angioplasty, infra-inguinal disease, peripheral interventions.

\section{Introduction}

The incidence of peripheral arterial disease (PAD) increases with age and the presence of risk factors [1]. Claudication and critical limb ischemia (CLI) are common presentations of these patients [2]. CLI accounts

\author{
Corresponding author: \\ Obai Abdullah MD \\ Cardiovascular Medicine \\ Department \\ University of Missouri \\ Columbia School \\ of Medicine \\ 1 Hospital Dr \\ Columbia, MO 65212 \\ USA \\ Phone: (573) 529-9454 \\ Fax: (573) 884-7742 \\ E-mail: abdullaho@health. \\ missouri.edu, \\ dr_omfa@hotmail.com
}


for $70-80 \%$ of major lower limb amputations $[3,4]$. The efficacy of balloon angioplasty (PTA) is well established in the treatment of focal vascular occlusive disease and has resulted in good limb salvage in patients with CLI. However, it is susceptible to acute vessel recoil and a high restenosis rate especially in cases of eccentric and severely calcified atherosclerotic lesions [5-8]. Additional techniques such as atherectomy and stenting are used to improve the efficacy of PTA mainly by lowering residual stenosis after angioplasty and improving long-term patency [9]. Plaque excision using ATHERO devices offers the advantage of removing the obstructive plaques in heavily calcified vessels but its role and cost-effectiveness remain controversial [10, 11].

This analysis aimed to compare outcomes associated with ATHERO versus PTA for the treatment of infra-inguinal PAD.

\section{Material and methods}

Medline, PubMed and the Cochrane Central Register of Controlled Trials were queried from Feb 1995 to May 2018. Only studies comparing ATHERO with PTA were included.

\section{Inclusion and exclusion criteria}

Studies comparing ATHERO versus PTA for symptomatic infra-inguinal PAD, double-armed, and published in the English language were included irrespective of the date of publication. Non-infra-inguinal PAD, use of drug-coated balloons (DCB), unpublished data, non-English language articles, single-armed studies, review articles, commentaries, letters, case reports, animal and in-vitro studies were excluded.

The initial search identified (450) citations. Three hundred citations were excluded due to not meeting inclusion criteria or investigating a different outcome. The final search identified eight original papers that fulfilled the criteria for inclusion and exclusion. Figure 1 identifies the study selection process.

\section{Device description}

Chosen devices included a transcutaneous extraction catheter (TEC), Excimer laser ATHERO, Diamondback 360 orbital ATHERO, SilverHawk Directional ATHERO, and Simpson Directional ATHERO (Table I). PTA was performed with appropriately sized balloons [12-15] and balloon inflation times ranged from 60 to 180 seconds in four studies $[12,13,15,16]$. There were sparse data regarding the frequency of inflations.

\section{Data extraction}

Data elements were extracted from included studies by two independent reviewers (OA \& TE)
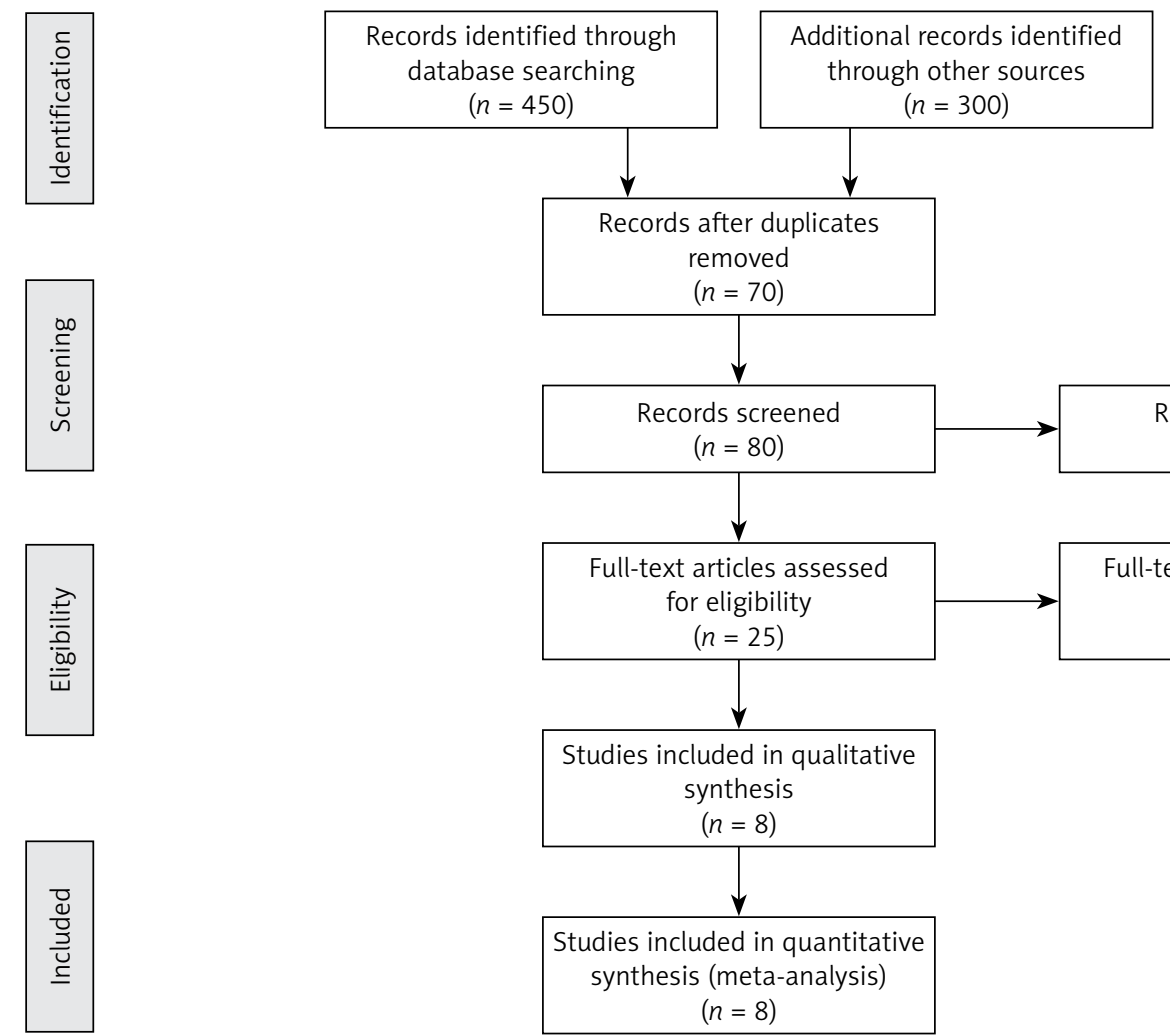

Figure 1. PRISMA Flow data chart 
Table I. Details for the chosen devices

\begin{tabular}{|c|c|c|c|}
\hline Study/year & Chosen device & Company & Mechanism of action \\
\hline Nakamura/1995 & $\begin{array}{c}\text { Transcutaneous extraction } \\
\text { catheter (TEC) }\end{array}$ & Not reported & $\begin{array}{c}\text { Excises and aspirates } \\
\text { atheroma [10] }\end{array}$ \\
\hline Shammas/2013 & $\begin{array}{c}\text { Diamondback } 360 \text { orbital } \\
\text { atherectomy }\end{array}$ & $\begin{array}{l}\text { Cardiovascular Systems, Inc., } \\
\text { St. Paul, MN, USA }[11,13]\end{array}$ & $\begin{array}{l}\text { Eccentric diamond-coated } \\
\text { crown on the end of } \\
\text { a drive shaft powered by } \\
\text { a pneumatic drive console }\end{array}$ \\
\hline $\begin{array}{l}\text { Ott/2017, Tan/2011, } \\
\text { Shammas/2011 }\end{array}$ & $\begin{array}{c}\text { SilverHawk Directional } \\
\text { atherectomy }\end{array}$ & $\begin{array}{c}\text { ev3 Endovascular Inc [14], } \\
\text { Covidien [15, 16], (ev3, } \\
\text { Plymouth, Minnesota } \\
\text { [17]), (ev3 Endovascular } \\
\text { Inc Plymouth, Minn, and } \\
\text { FoxHollow Technologies Inc., } \\
\text { Redwood City, CA, USA [11]) }\end{array}$ & $\begin{array}{l}\text { Uses a cutting blade to } \\
\text { shave and excise plaque }\end{array}$ \\
\hline Vroegindeweij/1995 & $\begin{array}{l}\text { Simpson Directional } \\
\text { atherectomy }\end{array}$ & $\begin{array}{c}\text { Devices for Vascular } \\
\text { Intervention, Inc., Redwood } \\
\text { City, CA [18] }\end{array}$ & \\
\hline
\end{tabular}

using a pre-specified datasheet. These included baseline demographics, lesion characteristics, study design, sample size, type of endovascular intervention, and endpoints of interest. One review author extracted the data from included studies when available and a second author verified the extracted data.

\section{Study endpoints, device and balloon description}

Study endpoints were classified into procedural and clinical endpoints. Procedural endpoints included vessel dissection, distal embolization, residual stenosis (> 30\%), and vessel patency at 6 months. Clinical endpoints included target lesion revascularization (TLR) at 12 months, and major amputation rates at 1,6 and 12 months. All reported amputations were major. Embolization was evaluated by debris captured in the filter when the distal protection device was used. Assessment of residual stenosis was made angiographically, by intravascular ultrasound (IVUS) or via quantitative vascular analysis. Dissections were assessed angiographically or by IVUS and were classified into small, large, type A through $\mathrm{F}$ or flow-limiting. The severity of calcification was evaluated fluoroscopically or scored as none to severe (Table II).

\section{Risk of bias assessment}

Methodological quality was defined as the control of bias assessed through the reported methods in each individual study using the Cochrane risk of bias tool to assess the quality of randomized trials [17]. The Newcastle-Ottawa Scale (NOS) was used to assess the quality of observational studies [18]. This method tests for several types of biases and classifies them into low, intermediate or high risk based on the authors' judgment. There was a risk of inadequate randomization, lack of allocation concealment, lack of blinding and inadequate baseline characteristics matching for prospective studies. Attrition bias was intermediate in one study and low in the remaining four prospective studies (Table III). There was no evidence of high risk of inadequate representativeness or comparability of the cohorts. There was adequate ascertainment of exposure to the interventions of interest, absence of the outcomes at the beginning of the studies and an adequate follow-up period in all retrospective studies (Table IV). The funnel plot test showed no high risk of publication bias by showing symmetrical distribution of the studies (Figure 2).

\section{Statistical analysis and data synthesis}

From the abstracted data, we calculated the odds ratio (OR) using the inverse variance method for each study outcome to allow for the pooling of similar outcomes. The average effects for the outcomes and the $95 \%$ confidence intervals (Cl) were obtained using a random-effects model, as described by DerSimonian [19].

To assess heterogeneity of the treatment effect among trials, we used the $I^{2}$ statistic. The $I^{2}$ statistic represents the proportion of heterogeneity of the treatment effect across trials that was not attributable to chance or random error. Hence, a value of $50 \%$ or higher reflects significant heterogeneity that is due to real differences in study populations, protocols, interventions, and outcomes [19]. The $p$-value threshold for statistical significance was set at 0.05 for effect sizes. Analyses were conducted using features in RevMan version 5.3.5 (The Nordic Cochrane Center, Copenhagen, Denmark). The study was performed in accordance with the recommendations set forth by the Preferred Reporting Items for Systematic Reviews and MetaAnalyses (PRISMA) workgroup [20]. 
Table II. Details on the use of distal protection, residual stenosis, dissection, calcification, and patency assessment

\begin{tabular}{|c|c|c|c|c|c|c|}
\hline Study/year & $\begin{array}{l}\text { Use of distal } \\
\text { protection }\end{array}$ & $\begin{array}{c}\text { Assessment } \\
\text { of residual } \\
\text { stenosis }\end{array}$ & $\begin{array}{l}\text { Dissections } \\
\text { assessment }\end{array}$ & $\begin{array}{l}\text { Types of } \\
\text { dissections }\end{array}$ & $\begin{array}{l}\text { Calcification } \\
\text { assessment }\end{array}$ & $\begin{array}{c}\text { Patency } \\
\text { assessment }\end{array}$ \\
\hline $\begin{array}{l}\text { Nakamura/ } \\
1995\end{array}$ & NA & IVUS & $\begin{array}{l}\text { Angiographi- } \\
\text { cally + IVUS }\end{array}$ & NA & $\begin{array}{l}\text { Scored as } \\
\text { none to } \\
\text { severe }\end{array}$ & NA \\
\hline $\begin{array}{l}\text { Vroegindeweij/ } \\
1995\end{array}$ & NA & $\begin{array}{l}\text { Angiograph- } \\
\text { ically }\end{array}$ & NA & $\begin{array}{l}\text { Used the } \\
\text { term small } \\
\text { and large for } \\
\text { dissections }\end{array}$ & NA & $\begin{array}{l}\text { Color-flow } \\
\text { duplex sur- } \\
\text { veillance }\end{array}$ \\
\hline Tan/2011 & NA & $\begin{array}{l}\text { Angiograph- } \\
\text { ically }\end{array}$ & NA & NA & NA & $\begin{array}{c}\text { Freedom from } \\
\text { reintervention } \\
\text { and changes } \\
\text { in } \mathrm{ABI}\end{array}$ \\
\hline Gallagher/2011 & $\begin{array}{l}\text { Yes; at the } \\
\text { discretion of } \\
\text { the operat- } \\
\text { ing surgeon } \\
\text { ( } 25 \% \text { of } \\
\text { atherectomy } \\
\text { procedures) }\end{array}$ & $\begin{array}{l}\text { Angiograph- } \\
\text { ically }\end{array}$ & NA & $\begin{array}{l}\text { Flow limiting } \\
\text { dissections }\end{array}$ & NA & $\begin{array}{c}\text { Physical } \\
\text { examinations } \\
\text { and physical } \\
\text { examinations } \\
\text { and an } A B \mid \\
<0.4\end{array}$ \\
\hline Shammas/2011 & $\begin{array}{l}\text { Yes; but not } \\
\text { mandated by } \\
\text { the protocol } \\
\text { and was used } \\
\text { more com- } \\
\text { monly in the } \\
\text { atherectomy } \\
\text { group }\end{array}$ & $\begin{array}{l}\text { Angiograph- } \\
\text { ically }\end{array}$ & $\begin{array}{l}\text { Angiograph- } \\
\text { ically }\end{array}$ & $\begin{array}{l}\text { Included } \\
\text { all types of } \\
\text { dissection } \\
\text { (A to F) }\end{array}$ & $\begin{array}{c}\text { Excluded } \\
\text { heavily calci- } \\
\text { fied vessels } \\
\text { as subjective- } \\
\text { ly determined } \\
\text { by the oper- } \\
\text { ator }\end{array}$ & NA \\
\hline Shammas/2012 & NA & $\begin{array}{l}\text { Via quantita- } \\
\text { tive vascular } \\
\text { analysis }\end{array}$ & NA & $\begin{array}{l}\text { Included } \\
\text { all types of } \\
\text { dissection } \\
\text { (A to F) }\end{array}$ & $\begin{array}{l}\text { Fluoroscop- } \\
\text { ically visible } \\
\text { calcium of } \\
\text { more than or } \\
\text { equal to } 25 \% \\
\text { of the treated } \\
\text { segment }\end{array}$ & NA \\
\hline Reynolds/2013 & NA & NA & NA & NA & NA & NA \\
\hline Ott/2017 & $\begin{array}{l}\text { Yes; in the } \\
\text { atherectomy } \\
\text { group }\end{array}$ & $\begin{array}{l}\text { Angiograph- } \\
\text { ically }\end{array}$ & $\begin{array}{l}\text { Angiograph- } \\
\text { ically }\end{array}$ & $\begin{array}{l}\text { Flow limiting } \\
\text { dissections }\end{array}$ & $\begin{array}{c}\text { Scored as } \\
\text { none to } \\
\text { severe }\end{array}$ & NA \\
\hline
\end{tabular}

Table III. Bias risk assessment of prospective studies

\begin{tabular}{|lccccccc|}
\hline Study ID & Study Design & $\begin{array}{c}\text { Adequate } \\
\text { Random- } \\
\text { ization }\end{array}$ & $\begin{array}{c}\text { Allocation } \\
\text { conceal- } \\
\text { ment }\end{array}$ & Blinding & $\begin{array}{c}\text { Baseline } \\
\text { charac- } \\
\text { teristics } \\
\text { Balanced }\end{array}$ & $\begin{array}{c}\text { Lost to fol- } \\
\text { low-up \% }\end{array}$ & $\begin{array}{c}\text { Incomplete } \\
\text { data (attri- } \\
\text { tion bias) }\end{array}$ \\
\hline $\begin{array}{l}\text { Vroegindeweij/ } \\
1995\end{array}$ & $\begin{array}{c}\text { Prospective } \\
\text { (randomized) }\end{array}$ & Yes & No & No & Yes & 1.46 & $\begin{array}{c}\text { Intermedi- } \\
\text { ate risk }\end{array}$ \\
\hline $\begin{array}{l}\text { Nakamura/ } \\
1995\end{array}$ & $\begin{array}{c}\text { Prospective } \\
\text { (randomized) }\end{array}$ & Yes & No & No & Yes & 0 & Low risk \\
\hline $\begin{array}{l}\text { Shammas/ } \\
2011\end{array}$ & $\begin{array}{c}\text { Prospective } \\
\text { (randomized) }\end{array}$ & Yes & No & No & Yes & 0 & Low risk \\
\hline $\begin{array}{l}\text { Shammas/ } \\
2012\end{array}$ & $\begin{array}{c}\text { Prospective } \\
\text { (randomized) }\end{array}$ & Yes & No & No & Yes & 0 & Low risk \\
\hline Ott/2017 & $\begin{array}{c}\text { Prospective } \\
\text { (randomized) }\end{array}$ & Yes & No & No & Yes & 22.47 & Low risk \\
\hline
\end{tabular}


Table IV. Bias risk assessment of retrospective observational studies

\begin{tabular}{|c|c|c|c|c|c|c|c|}
\hline \multirow[t]{2}{*}{ Study ID } & \multirow{2}{*}{$\begin{array}{l}\text { Study } \\
\text { design }\end{array}$} & \multicolumn{4}{|c|}{ Selection } & \multicolumn{2}{|c|}{ Outcome } \\
\hline & & $\begin{array}{c}\text { Represen- } \\
\text { tativeness } \\
\text { of exposed } \\
\text { cohort }\end{array}$ & $\begin{array}{l}\text { Compara- } \\
\text { bility }\end{array}$ & $\begin{array}{l}\text { Ascertain- } \\
\text { ment of } \\
\text { exposure }\end{array}$ & $\begin{array}{l}\text { Demonstra- } \\
\text { tion that } \\
\text { outcome of } \\
\text { interest was } \\
\text { not present } \\
\text { at start of } \\
\text { study }\end{array}$ & $\begin{array}{l}\text { Assessment } \\
\text { of outcome }\end{array}$ & $\begin{array}{l}\text { Enough } \\
\text { follow-up } \\
\text { length }\end{array}$ \\
\hline Tan/2011 & Cohort & $\begin{array}{l}\text { Truly repre- } \\
\text { sentative }\end{array}$ & Single center & $\begin{array}{l}\text { Secured } \\
\text { records }\end{array}$ & Yes & $\begin{array}{l}\text { Independent } \\
\text { assessment }\end{array}$ & $\begin{array}{l}\text { No (retro- } \\
\text { spective } \\
\text { study) }\end{array}$ \\
\hline $\begin{array}{l}\text { Gallagher/ } \\
2011\end{array}$ & Cohort & $\begin{array}{l}\text { Truly repre- } \\
\text { sentative }\end{array}$ & Single center & $\begin{array}{l}\text { Secured } \\
\text { records }\end{array}$ & Yes & $\begin{array}{l}\text { Independent } \\
\text { assessment }\end{array}$ & $\begin{array}{l}\text { No (retro- } \\
\text { spective } \\
\text { study) }\end{array}$ \\
\hline $\begin{array}{l}\text { Reynold/ } \\
2013\end{array}$ & Cohort & $\begin{array}{l}\text { Truly repre- } \\
\text { sentative }\end{array}$ & Multicenter & $\begin{array}{l}\text { Secured } \\
\text { records }\end{array}$ & Yes & $\begin{array}{l}\text { Independent } \\
\text { assessment }\end{array}$ & $\begin{array}{l}\text { No (retro- } \\
\text { spective } \\
\text { study) }\end{array}$ \\
\hline
\end{tabular}

Methods for including zero events in both arms

In the case of zero events for an endpoint in both arms of an included study simultaneously, we used the continuity factor of 1 added to all arms to avoid computational errors. Studies without reported outcomes were not included in the analysis [21].

\section{Results}

A total of 2923 patients (mean: 70.0 years; $61.5 \%$ male) were included from 8 studies ( 5 randomized prospective, and 3 observational retrospective) comparing ATHERO with PTA in patients with symptomatic infra-inguinal PAD between February 1995 to May 2018, all published in peer-reviewed journals [12-16, 22-24]. Approximately $85 \%$ of patients had critical limb ischemia and $15 \%$ had claudication. Both groups were comparable in terms of gender and the presence of diabetes. Hypertension, however, was higher in the ATHERO group (69\% vs. $54 \%$ ) (Table V).

The ATHERO intervention group included 960 patients with 1115 lesions. ATHERO alone was performed on $38 \%$ of lesions. The rest included ATHERO + PTA, ATHERO + stenting, and ATHERO + PTA + stenting. The PTA group included 1963 patients with 2114 lesions. PTA alone was performed on $70 \%$ of the lesions and PTA + stenting on the remaining 30\% (Table VI).

Four studies reported rates of distal embolization in relation to the total number of lesions and there was no significant difference between ATHERO and PTA groups $(\mathrm{OR}=0.45$ with $95 \% \mathrm{Cl}$ : $0.04-4.63, p=0.50$; Figure 3). Five studies reported residual stenosis rates in relation to the total number of lesions and there was no significant difference between the two groups ( $\mathrm{OR}=1.28$ with

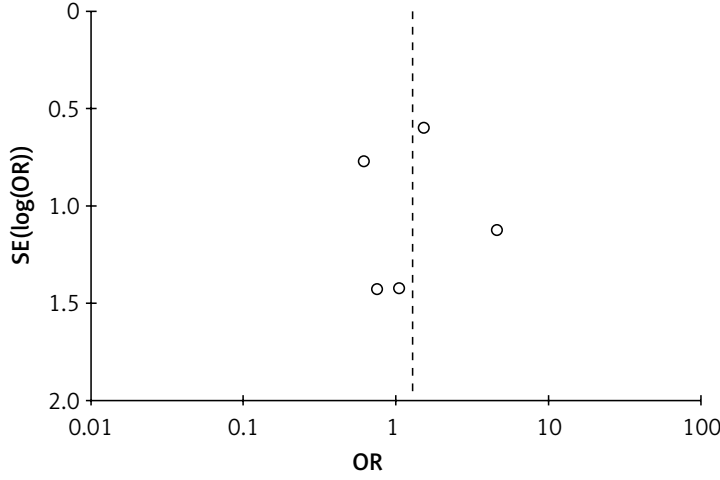

Figure 2. Funnel plot

95\% Cl: 0.58-2.80, $p=0.54$, Figure 4). Only two studies reported vessel patency rates in relation to the total number of lesions at 6 months and there was no significant difference $(\mathrm{OR}=1.27$ with 95\% Cl: 0.50-3.22, $p=0.61$, Figure 5). Three studies reported TLR rates in relation to the total number of patients at 12 months. Similarly, there was no significant difference between the two groups $(\mathrm{OR}=1.07$ with $95 \% \mathrm{Cl}: 0.46-2.51, p=0.87$, Figure 6).

Major limb amputation rates were evaluated at 1 month in 5 studies, at 6 months in 3 studies and at 12 months in 4 studies. There was no significant difference between ATHERO and PTA at 1 month $(\mathrm{OR}=0.69$ with $95 \% \mathrm{Cl}: 0.44-1.07, p=$ 0.10 ; Figure $7 \mathrm{~A})$ and 6 months $(\mathrm{OR}=1.54$ with 95\% Cl: 0.38-6.15, $p=0.54$, Figure 7 B). However, PTA was associated with a lower major amputation rate when compared with PTA at 12 months of follow-up (OR $=0.73$ with $95 \% \mathrm{Cl}$ : 0.59-0.90, $p=0.004$, Figure $7 \mathrm{C}$ ). Three studies reported dissection rates in relation to the total number of lesions and PTA was associated with a higher rate of vessel dissection when compared to PTA (OR = 4.00 with $95 \% \mathrm{Cl}: 1.15-13.86, p=0.03$, Figure 8). 


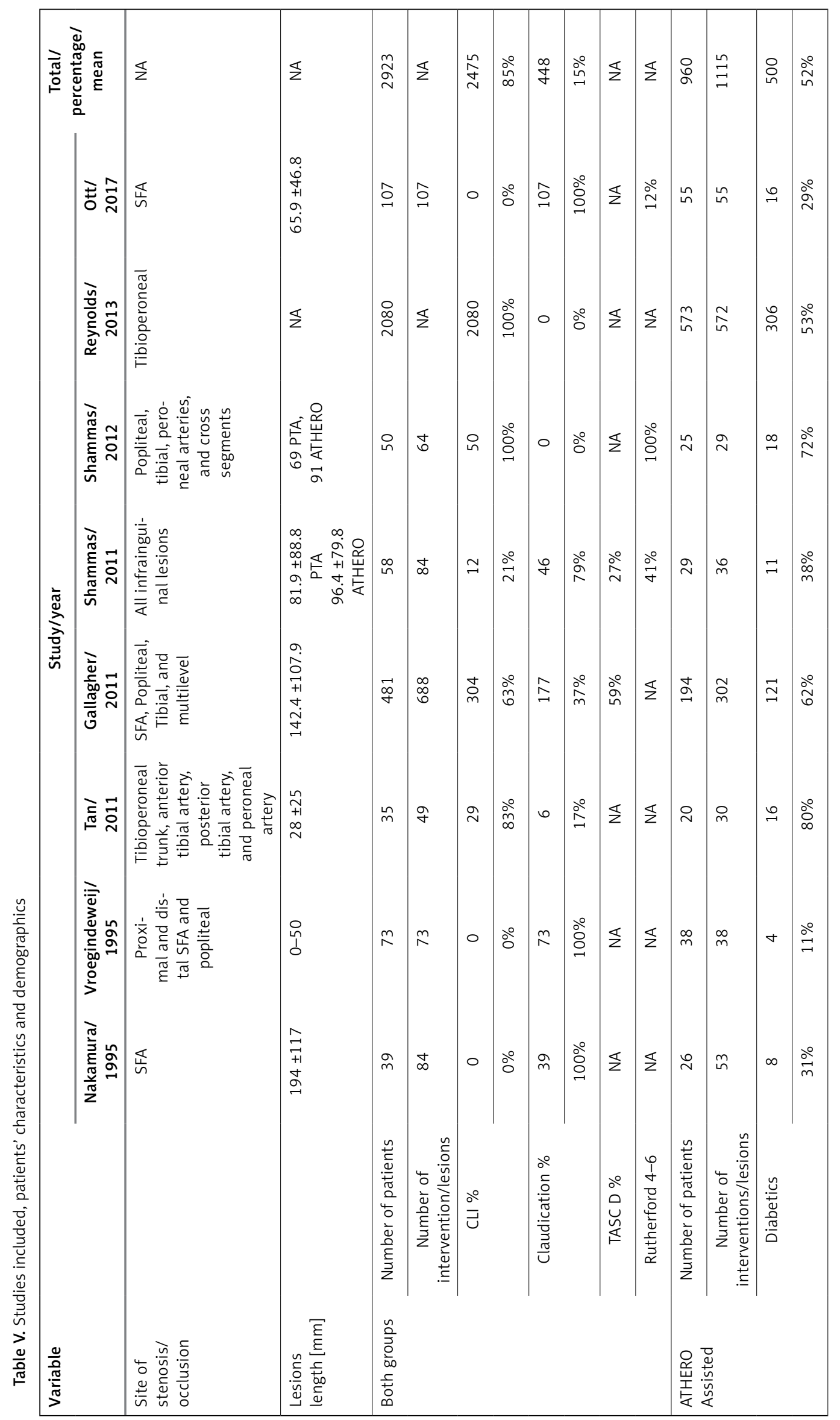




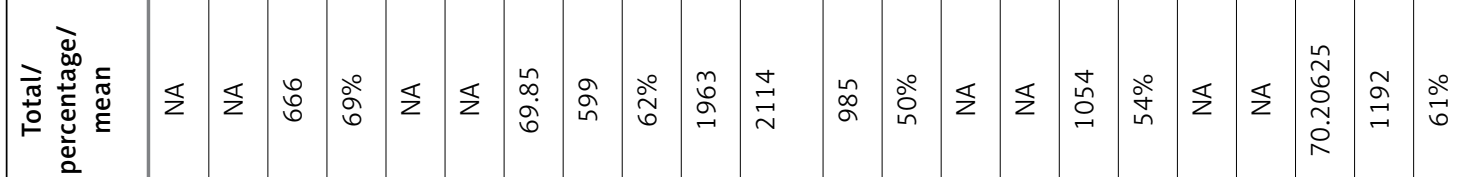

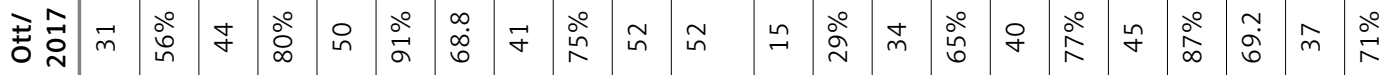

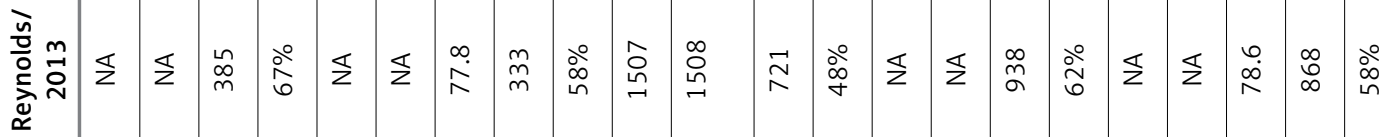

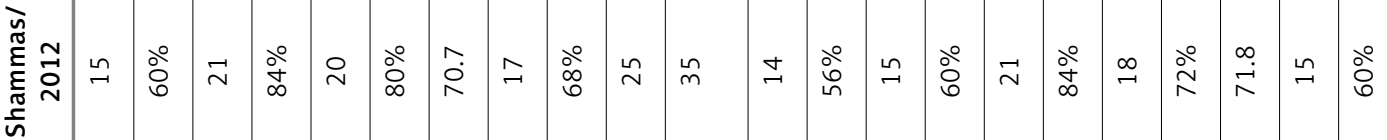

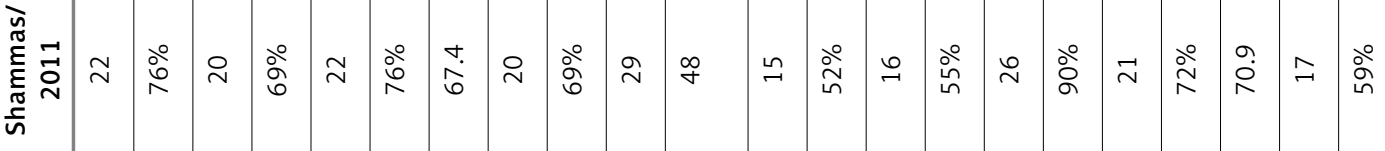

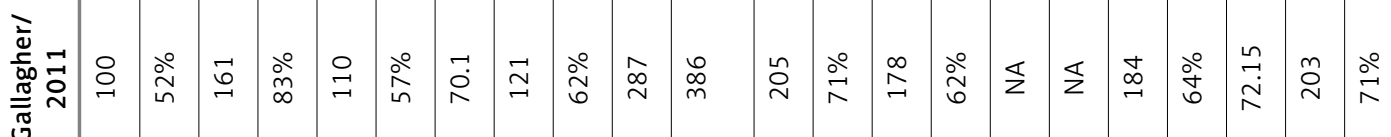

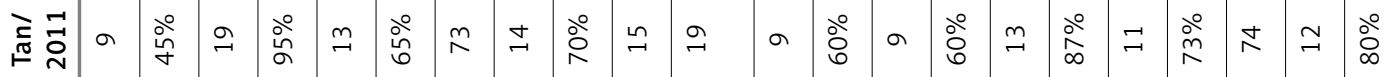
:⿳亠二口犬

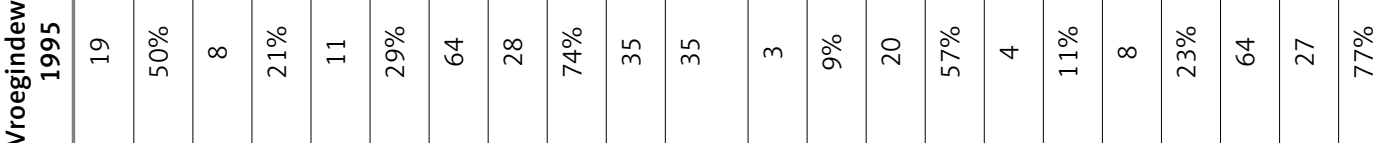

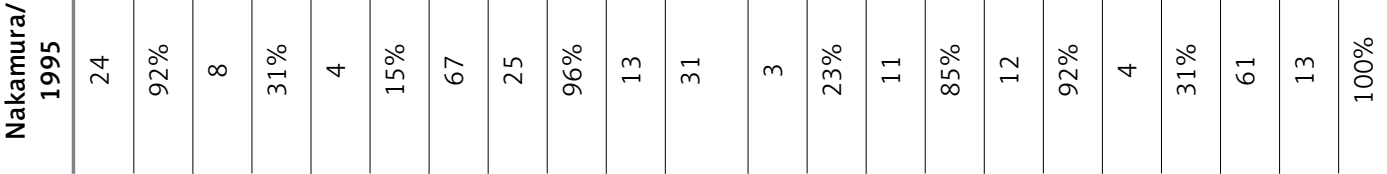

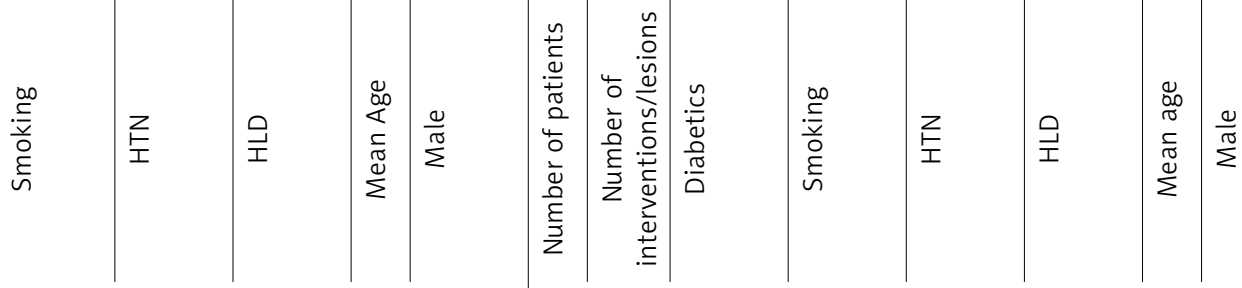




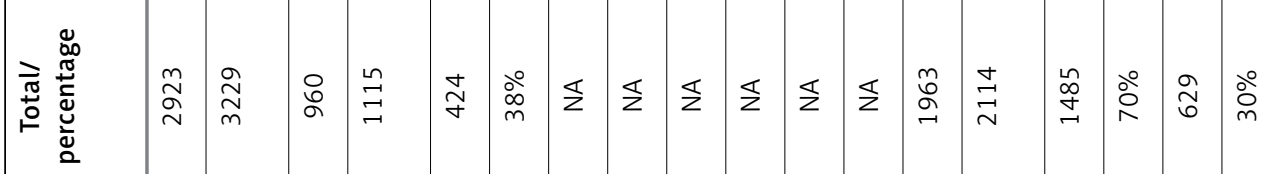

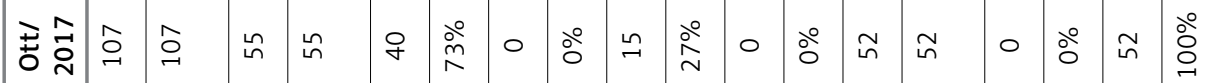

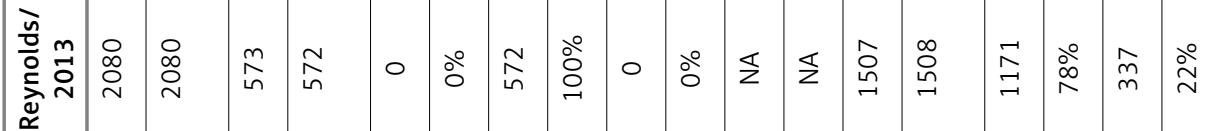

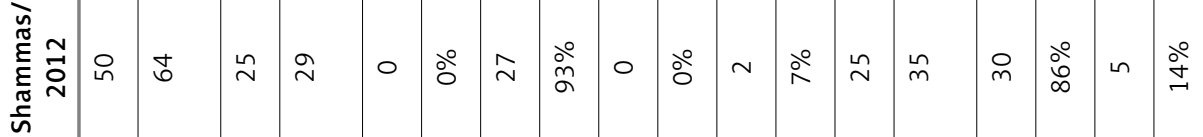

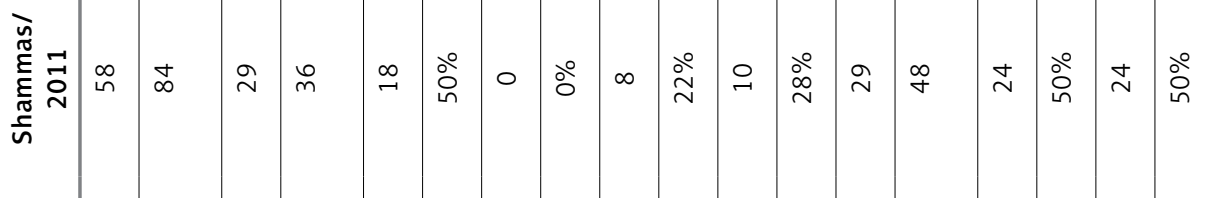

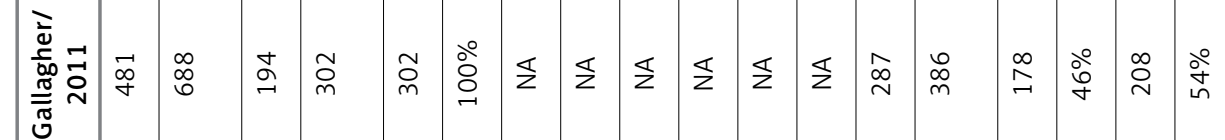

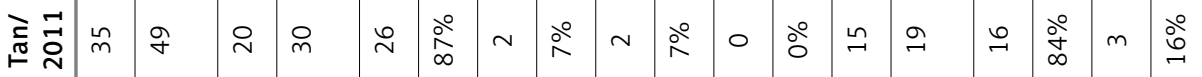

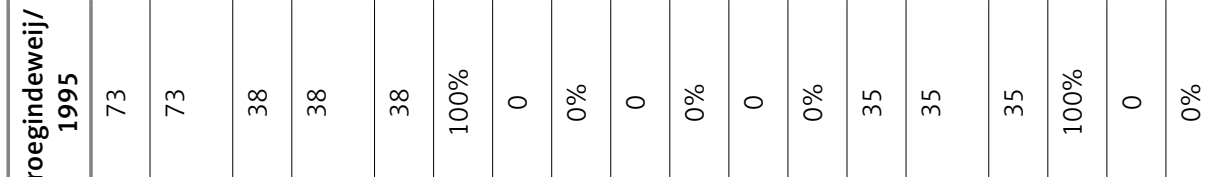

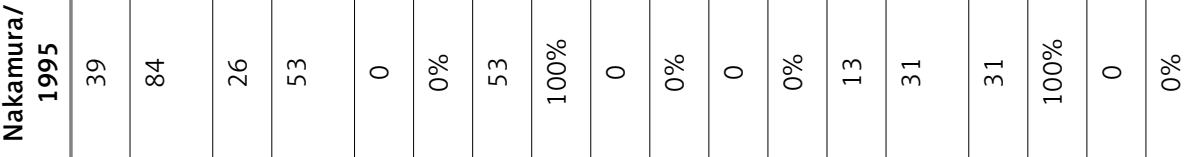

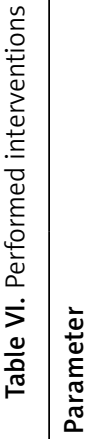

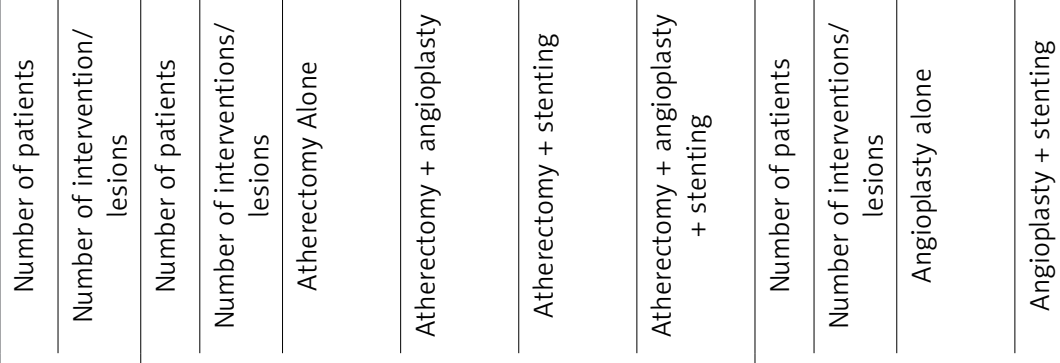

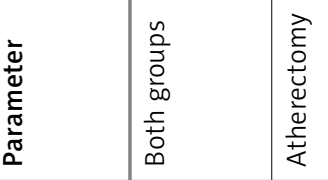

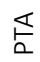




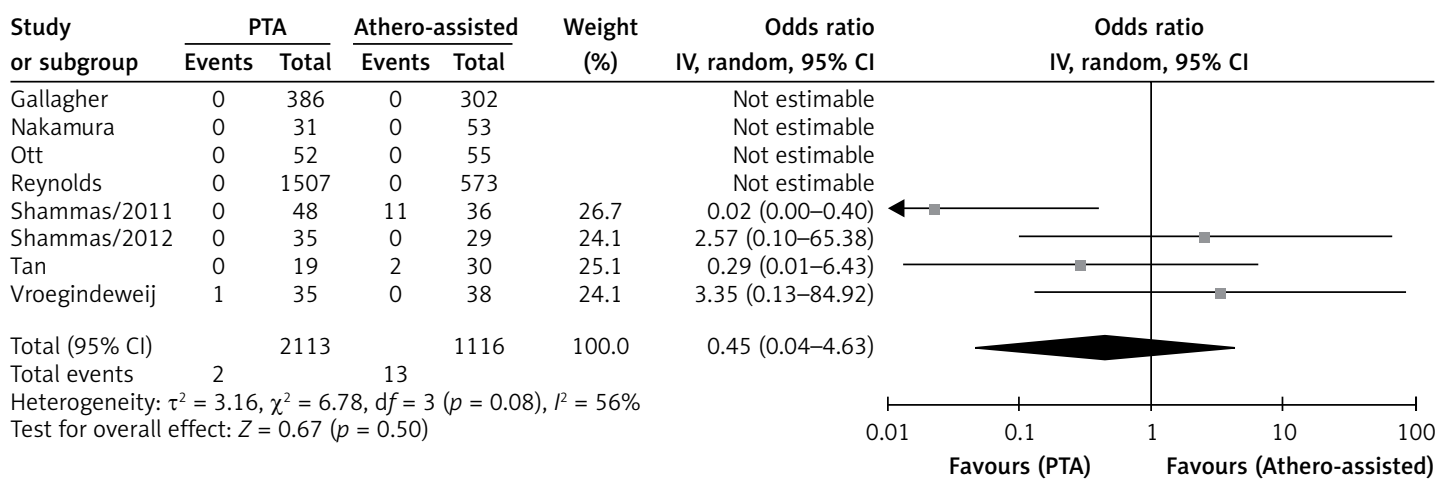

Figure 3. Embolization (per lesion)

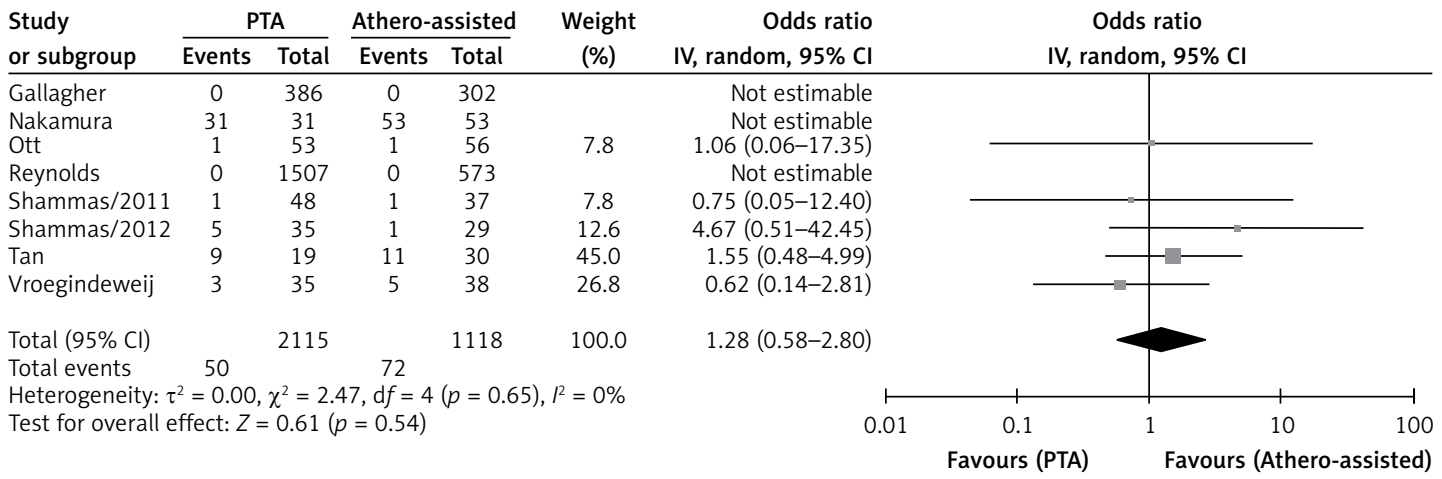

Figure 4. Residual stenosis > 30\% (per lesion)

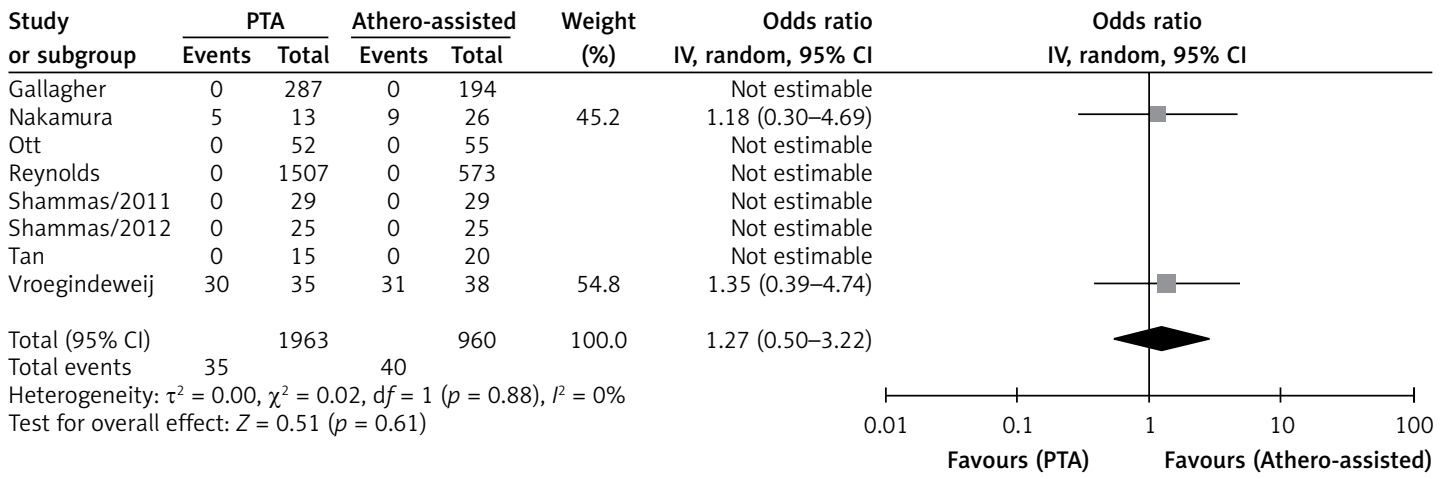

Figure 5. Six-month patency (per patient)

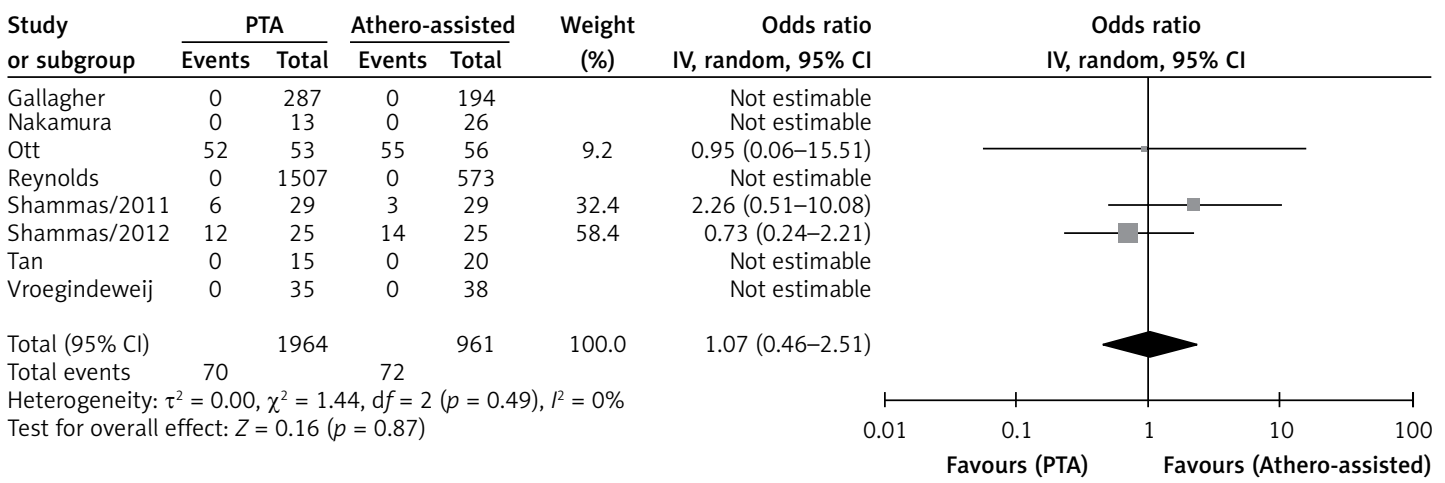

Figure 6. 12-month TLR (per patient) 


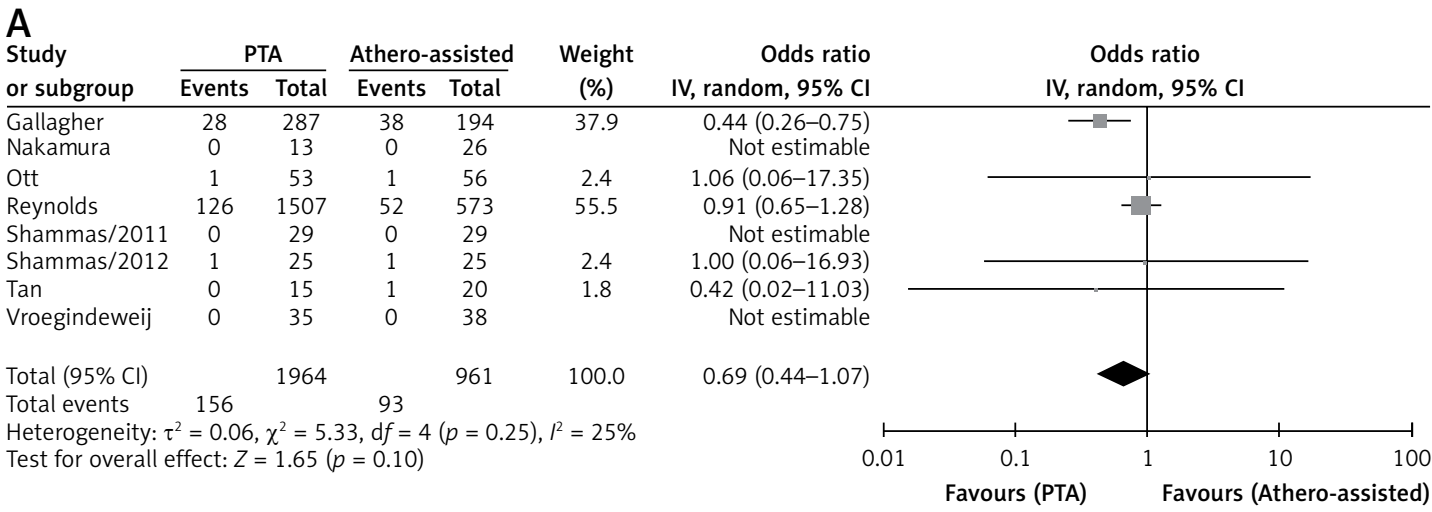

B

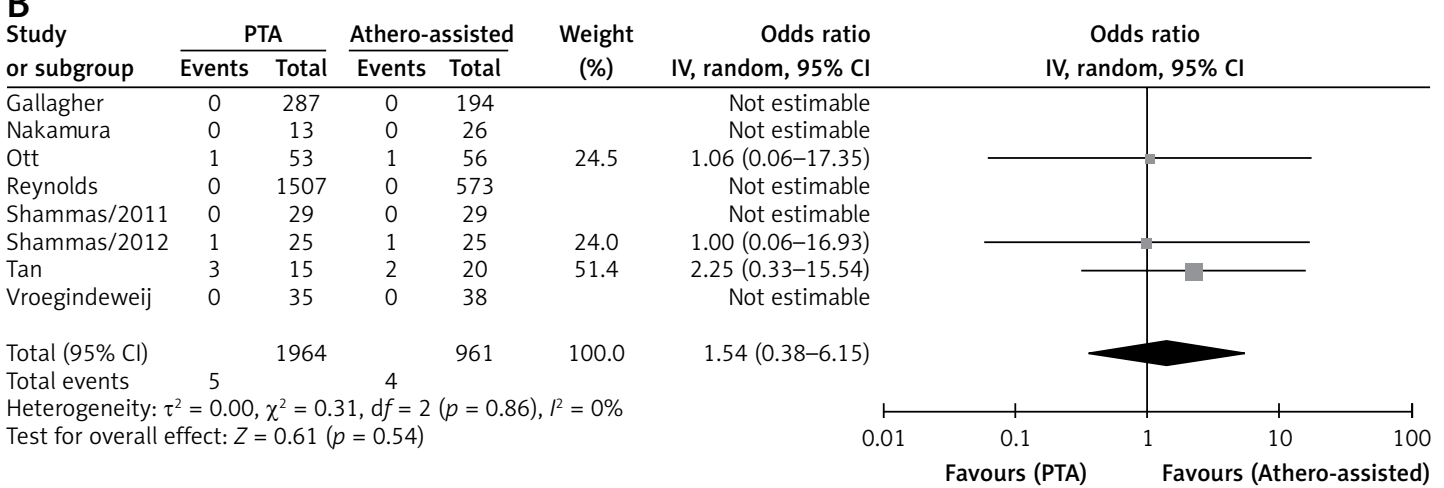

C

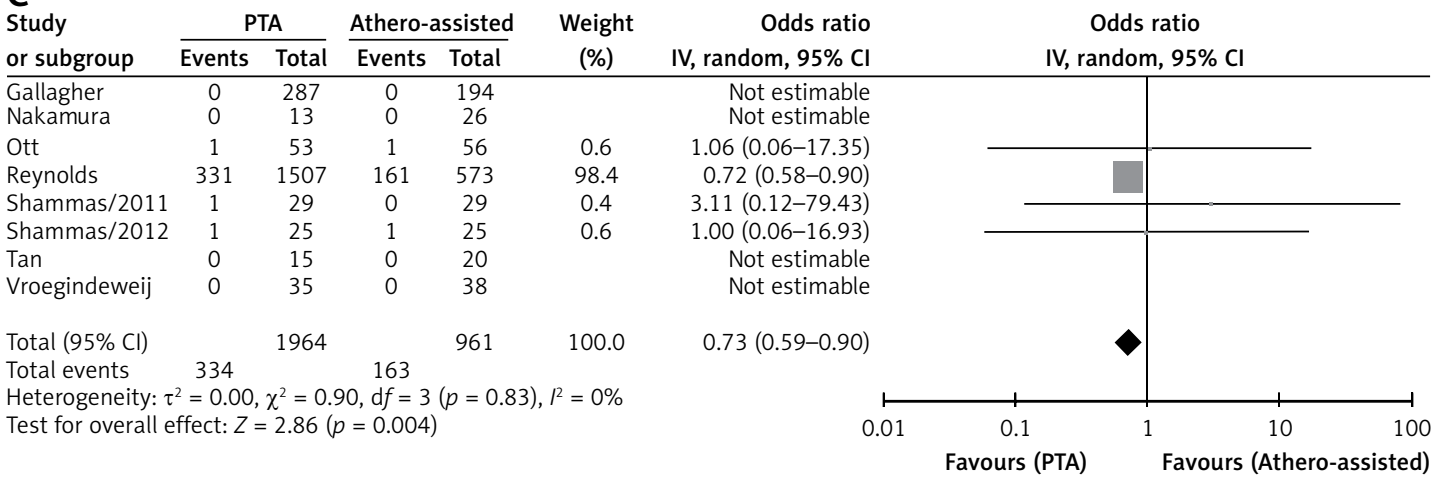

Figure 7. A - 1-month amputation (per patient). B - 6-month amputation (per patient). C - 12-month amputation (per patient)

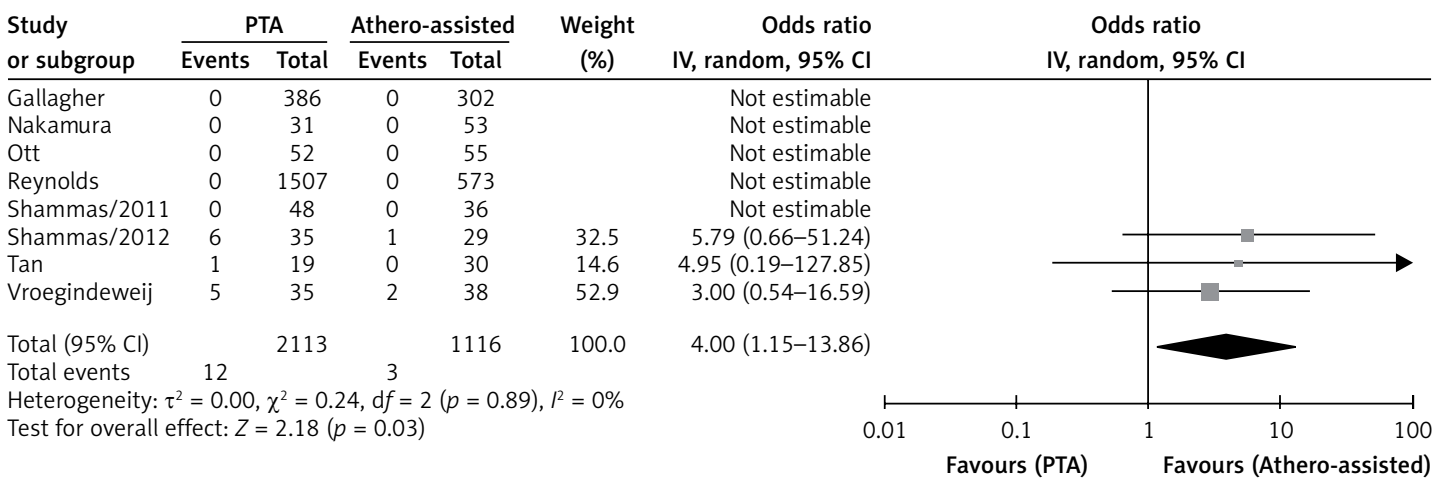

Figure 8. Dissection (per lesion) 


\section{Other analyses}

We chose the random effects method as the primary analysis because of its conservative summary estimate and incorporation of between- and within-study variance. When the analysis was repeated using the fixed-effect method, the results remained unchanged.

Sensitivity analysis was performed to assess the effects of selected measures of study design/ size on the pooled effect of ATHERO and PTA. The influence was estimated by performing a subgroup analysis and test for subgroup differences. The subgroup analysis was performed on the seven studies after excluding the largest study by Reynolds et al. [14-16, 22-24]. The results remained unchanged except for the statistically significantly lower 12-month amputation rates in the PTA group, which became insignificant.

\section{Discussion}

In this meta-analysis, we observed comparable endpoints when comparing ATHERO with PTA in terms of distal embolization, residual stenosis, vessel patency at 6 months, TLR at 12 months, and 1 - and 6-month major amputation rates. Although ATHERO was associated with lower vessel dissection, it was associated with higher major amputation rates at 12 months.

Previous data reported an increased risk of distal embolization associated with ATHERO in general, and with PTA when used for long complex lesions [25-27]. This study showed a similar risk for both modalities, which suggests that dislodgment of debris is independent of the strategy used. Since embolic filter protection is mostly used with ATHERO, this could have underestimated the distal embolization in this group. The rate of embolization differs between devices. In one study that included 10,875 procedures, embolization was reported to be the highest with excisional atherectomy, followed by laser atherectomy, followed by orbital atherectomy (5.1\% vs. $4.4 \%$ vs. $4.1 \%$, respectively) then PTA [25].

Theoretically, ATHERO should be associated with lower residual stenosis; however, this study shows similar residual stenosis between ATHERO and PTA. This could be explained by the difference in efficacy between used ATHERO devices (residual stenosis of $\leq 30 \%$ seen in $45-62 \%$ of patients with Directional atherectomy vs. $56 \%$ with Orbital and $0 \%$ with transluminal extraction (TEC) ATHERO device) [13-16, 24]. Further analysis was not possible with some studies either not indicating the type of device used or using different devices. Additionally, the created debris induced by PTA and/or ATHERO devices could have contributed to these findings.

Data regarding the primary patency rate at 6-month and 12-month target lesion revascular- ization (TLR) were lacking in most of the studies. However, available data showed no significant difference between the two modalities. These results could be explained by the endothelial damage and the generalized endothelial dysfunction induced by these devices.

The severity of illness, the degree of amputation, gender, comorbidities and endothelial dysfunction all are factors to consider when evaluating amputation rates. This study indicates similar major amputation rates at 1 and 6 months. However, ATHERO was associated with a higher 12-month rate of major amputation than PTA. This result was mainly driven by the largest study by Reynold et al. [22]. Subgroups analyses, after excluding the largest study, did not show higher amputation rates with ATHERO. That correlation could possibly be a statistical coincidence since 1- and 6-month major amputation rates were not different.

Vessel dissection rates were lower in the ATHERO group, which is consistent with current literature. This can be explained by improving vessel compliance with ATHERO when applied in calcified plaques or total occlusions leading to a lesser need for higher balloon inflation pressures $[26,27]$.

Drug-eluting stents (DES) have recently attracted interest as an alternative or adjunctive therapy to PTA. Paclitaxel-eluting stents showed superior clinical efficacy when compared with balloon angioplasty (BA) and standard stenting. Moreover, when comparing bare-metal stents (BMS) with sirolimus-eluting stents, the latter have shown significantly improved long-term event-free survival, amputation rates, and changes in Rutherford-Becker class after treatment of focal infra-popliteal lesions [28, 29].

This analysis has several limitations. It combines studies with variable designs and contains both retrospective and randomized prospective studies. Some of these studies were small and underpowered to assess clinical outcomes and they differed in the choice of primary endpoints. Furthermore, there were low events rates for some of the outcomes of interest. The presence of heterogeneity between studies is an important factor that should be acknowledged. Differences between baseline endovascular techniques between ATHERO and PTA groups, type of device used, lack of information regarding the severity of calcification in the treated vessel, and variability in operator experience and institution procedural volume are all contributors to the heterogeneity. Additionally, our results may not apply to newer atherectomy devices such as Pantheris, Phoenix, Rotarex, and JetStream, which were not included in our study.

In conclusion, this study shows that ATHERO was associated with lower vessel dissection. The 12-month major amputation rate was higher 
in the ATHERO group, but this result was driven by only one retrospective study and was not observed in the others. Otherwise, both strategies were associated with comparable procedural and clinical endpoints. With controversial data regarding ATHERO use in infra-inguinal PAD management and the fact that they significantly increase the procedural cost, there is a need for large randomized clinical trials to answer these questions and further define the role of ATHERO.

\section{Conflict of interest}

The authors declare no conflict of interest.

\section{References}

1. Hirsch AT, Criqui MH, Treat-Jacobson D, et al. Peripheral arterial disease detection, awareness, and treatment in primary care. JAMA 2001; 286: 1317-24.

2. Schainfeld RM. Management of peripheral arterial disease and intermittent claudication. J Am Board Fam Pract 2001; 14: 443-50.

3. Eskelinen E, Lepantalo M, Hietala EM, et al. Lower limb amputations in Southern Finland in 2000 and trends up to 2001. Eur J Vasc Endovasc Surg 2004; 27: 193-200.

4. Pohjolainen T, Alaranta $\mathrm{H}$. Lower limb amputations in southern Finland 1984-1985. Prosthet Orthot Int 1988; 12: 9-18.

5. Jaff MR, Nelson T, Ferko N, Martinson M, Anderson LH, Hollmann S. Endovascular interventions for femoropopliteal peripheral artery disease: a network meta-analysis of current technologies. J Vasc Interv Radiol 2017; 28: 1617-27e1.

6. Nakagawa N, Cragg AH, Smith TP, Landas SK, De Jong SC. Peripheral atherectomy: experimental results with a new device. J Vasc Interv Radiol 1990; 1: 127-32.

7. Katsanos K, Spiliopoulos S, Reppas L, Karnabatidis D. Debulking atherectomy in the peripheral arteries: is there a role and what is the evidence? Cardiovasc Intervent Radiol 2017; 40: 964-77.

8. Eskelinen E, Alback A, Roth WD, et al. Infra-inguinal percutaneous transluminal angioplasty for limb salvage: a retrospective analysis in a single center. Acta Radiol 2005; 46: 155-62.

9. Henry M, Amor M, Ethevenot G, Henry I, Allaoui M. Percutaneous peripheral atherectomy using the rotablator: a single-center experience. J Endovasc Surg 1995; 2: 51-66.

10. Kolakowski S Jr, Calligaro KD, Dougherty MJ. Is infrainguinal percutaneous atherectomy better suited for certain arteries than others? Vasc Endovascular Surg 2009; 43: 462-6.

11. Arain SA, White CJ. Endovascular therapy for critical limb ischemia. Vasc Med 2008; 13: 267-79.

12. Gallagher KA, Meltzer AJ, Ravin RA, et al. Endovascular management as first therapy for chronic total occlusion of the lower extremity arteries: comparison of balloon angioplasty, stenting, and directional atherectomy. J Endovasc Ther 2011; 18: 624-37.

13. Tan TW, Semaan E, Nasr W, et al. Endovascular revascularization of symptomatic infrapopliteal arteriosclerotic occlusive disease: comparison of atherectomy and angioplasty. Int J Angiol 2011; 20: 19-24.

14. Vroegindeweij D, Tielbeek AV, Buth J, Schol FP, Hop WC, Landman GH. Directional atherectomy versus balloon angioplasty in segmental femoropopliteal artery dis ease: two-year follow-up with color-flow duplex scanning. J Vasc Surg 1995; 21: 255-68; discussion 268-9.

15. Shammas NW, Lam R, Mustapha J, et al. Comparison of orbital atherectomy plus balloon angioplasty vs. balloon angioplasty alone in patients with critical limb ischemia: results of the CALCIUM 360 randomized pilot trial. J Endovasc Ther 2012; 19: 480-8.

16. Shammas NW, Coiner D, Shammas GA, Dippel EJ, Christensen L, Jerin M. Percutaneous lower-extremity arterial interventions with primary balloon angioplasty versus Silverhawk atherectomy and adjunctive balloon angioplasty: randomized trial. J Vasc Interv Radiol 2011; 22: 1223-8.

17. Juni P, Altman DG, Egger M. Systematic reviews in health care: assessing the quality of controlled clinical trials. BMJ 2001; 323: 42-6.

18. Wells Gea. The Newcastle-Ottawa Scale (NOS) for assessing the quality of nonrandomised studies in meta-analyses Available at: http://wwwohrica/programs/ clinical_epidemiology/oxfordasp, November 4, 2012.

19. Higgins JP, Thompson SG, Deeks JJ, Altman DG. Measuring inconsistency in meta-analyses. BMJ 2003; 327: 557-60.

20. Moher D, Liberati A, Tetzlaff J, Altman DG, Group P. Reprint--preferred reporting items for systematic reviews and meta-analyses: the PRISMA statement. Phys Ther 2009; 89: 873-80

21. Cheng J, Pullenayegum E, Marshall JK, lorio A, Thabane L. Impact of including or excluding both-armed zero-event studies on using standard meta-analysis methods for rare event outcome: a simulation study. BMJ Open 2016; 6: e010983.

22. Reynolds S, Galinanes EL, Dombrovskiy VY, Vogel TR. Longitudinal outcomes after tibioperoneal angioplasty alone compared to tibial stenting and atherectomy for critical limb ischemia. Vasc Endovascular Surg 2013; 47: 507-12.

23. Nakamura S, Conroy RM, Gordon IL, et al. A randomized trial of transcutaneous extraction atherectomy in femoral arteries: intravascular ultrasound observations. J Clin Ultrasound 1995; 23: 461-71.

24. Ott I, Cassese S, Groha P, et al. Randomized comparison of paclitaxel-eluting balloon and stenting versus plain balloon plus stenting versus directional atherectomy for femoral artery disease (ISAR-STATH). Circulation 2017; 135: 2218-26.

25. Ochoa Chaar Cl, Shebl F, Sumpio B, Dardik A, Indes J, Sarac T. Distal embolization during lower extremity endovascular interventions. J Vasc Surg 2017; 66: 143-50.

26. Zeller T, Sixt S, Schwarzwalder U, et al. Two-year results after directional atherectomy of infrapopliteal arteries with the SilverHawk device. J Endovasc Ther 2007; 14: 232-40.

27. Giles KA, Pomposelli FB, Spence TL, et al. Infrapopliteal angioplasty for critical limb ischemia: relation of TransAtlantic InterSociety Consensus class to outcome in 176 limbs. J Vasc Surg 2008; 48: 128-36.

28. Zeller T, Dake MD, Tepe G, et al. Treatment of femoropopliteal in-stent restenosis with paclitaxel-eluting stents. JACC Cardiovasc Interv 2013; 6: 274-81.

29. Rastan A, Brechtel K, Krankenberg H, et al. Sirolimuseluting stents for treatment of infrapopliteal arteries reduce clinical event rate compared to bare-metal stents: long-term results from a randomized trial. J Am Coll Cardiol 2012; 60: 587-91. 